\title{
太賢の戒律思想
}

一一特に三聚浄戒と「瑜伽戒」の影響について——

\section{李忠 煥}

新羅景徳王代（在位742-765）の法相宗の僧侶である太賢（生没未詳）は，多くの 著述で一心観と和猙思想を通して性・相の猙論を融合した思想を展開している. 特に『梵網経古迹記』（以下『古迹記』）は，智顗（538-597）以後の註釈書のうちで, はじめて『梵網経』上下巻を註釈して『梵網経』を一乗教と見, 三聚浄戒を受容 して「梵網戒」に七衆戒と瑜伽戒を含ませた。

『古迹記』の特徵は, 三聚浄戒を導入して一切衆生の受戒と菩薩の「無違犯」 （菩薩の犯戒行を無犯と判断すること）を認める註釈を示したことである．特に菩薩 の無違犯については『瑜伽師地論』（以下『瑜伽論』）を引用してその根拠とした. 後世の『三国遺事』(一然, 高麗) に「賢瑜伽, 海華厳」と記されているように, 太賢は新羅瑜伽宗の祖師であり, 彼が『瑜伽論』を引用するのは当然のことであ ろう.

この『古迹記』の特徴について義寂・勝莊の影響を主張する先行研究があ る ${ }^{1)}$.しかし，太賢は勝荘 (生没未詳) の『梵網経述記』(以下『述記』）のように， 『瑜伽論』を優位に置いて註釈したのではなく，各戒条における自分の見解の根 拠として引用した。 また，「第一殺生戒」では先学たちの註釈と『瑜伽論』の内 容を否定しつつ独自の解釈を示す.

本研究は, 『古迹記』の特徴を太賢以前の註橎書と比較し, 『梵網経』註釈史に おける太賢の位置付けとともにその影響関係を明らかにしたい.

『梵網経』の註釈における三聚浄戒について, 従来の智顗, 元暁（618-676）は 『梵網経』に三聚浄戒が含まれていると説明するにとどまり，法蔵（643-712）は 「是故十戒一一皆具三聚」(T40.609c09) と述べて「十重戒」のみに限定した。 とこ ろが，太賢は「如此諸戒一一皆具三聚戒義」（T40.708c）と述べて, 十重四十八軽 戒の全体に三聚浄戒を組み入れた。さらに三聚浄戒の摂律儀戒を七衆戒と定義づ け，三聚浄戒による一切戒の包摂を一層明らかにした。 
この太賢の定義は，菩薩戒による出家を対象とした註釈であると考えられる. 三聚浄戒の導入によって『梵網経』は一切戒を包摂する戒本になり，既成の『四 分律』などの出家戒本との違いがなくなった。すなわち『梵網経』を受戒すれ ば，おのずから声聞戒も受戒することになるので，太賢は大乗菩薩の声聞戒と菩 薩戒の重受を否定する2).

そして，受戒法を「全分受」と「一分受」に分け3)，比丘戒のように二百五十 戒を受戒 (全分受) して成り立つのではなく，自分の状況などに合わせて一部だ けを受戒 (一分受) しても大乗の菩薩になると説く。これは義寂 (681-?) の『菩 薩戒本疏』（以下『義寂疏』）に説かれている「總受・別受」と類似した註釈であ る ${ }^{4)}$. しかし，義寂は摂律儀戒（七衆戒）に各々の受戒法があると説いたが，太 賢はより詳細な説明を加えて, 『梵網経』の諸戒に七衆戒が含まれているから， 「一分受」は一戒だけを受けても功徳は小乗戒より優れていると述べつつ、『梵網 経』による受戒の優越性を強調する ${ }^{5)}$.

また「自誓受戒」について，従来の智顗は下品の受戒であると説いたが6)，太 賢は「自誓受戒」も「従他受戒」も等しい心によって受戒するので，両受戒の福 徳に差別はないと反論する7)。これは戒体である心は区別をつけないものなの で，誰もが発心さえすれば，正式に受戒されて大乗菩薩になるのである.

太賢は戒の根本を仏性と見 ${ }^{8)}$ ，それを「如来性門・発趣相門」に分けて仏性は 「性相不二」の空性であると説く。これは元暁の『梵網経菩薩戒本私記』(以下『私 記』）の「真如心・生滅心」と類似した説明である. しかし，元暁は「生滅心」を 取り除いて「真如心」を顕現すれば成仏に至るというが，太賢は単に妄念によっ て迷ったことで，悟れば「性相不二」の空性であると説く．さらに『瑜伽論』を 引用し, 空性も実は方便であって, 空もまた空であることを理解したとき, 究竟 の菩薩行を修すると説き9 ${ }^{9}$, 一心観をより強く用いた註釈を示す.

一例を挙げると，太賢は菩薩の犯戒行を無犯とする「無違犯」を説く。これは 元暁『私記』の「挙非結過」, 法蔵『梵網経菩薩戒本疏』(以下『法蔵疏』) の「通 塞」にも表れている犯戒判断である。しかし, 元暁と法蔵は各戒条における特殊 な例として挙げていた無違犯を，太賢は犯戒判断の全面に展開してょり一般的な 例として活用した．特に太賢は「十重四十八軽戒」の十三箇所で『瑜伽論』を引 用して無違犯の論拠として用いた.

これについて崔源植は, 勝莊は 23 箇所, 義寂は 17 箇所で『瑜伽論』を引用し ており，三人は計10箇所で同じ『瑜伽論』を引用したといい，太賢は勝莊・義 
寂から影響を受けて『古迹記』を著したと主張する ${ }^{10)}$. 確かに引用文から見れ ば，勝莊・義寂の影響と考えることもできる．しかし「第一快意殺生戒」のよう に，太賢は彼らと同じ『瑜伽論』を引いているが，それを否定する場合もある． したがって, 単に『瑜伽論』の引用が一致する点から, その影響関係を確定する ことはできない.

如瑜伽説, 菩薩若見欲作重罪, 発心思惟, 我若断彼悪衆生命, 当墮地獄. 如其不断彼罪, 業成当受大苦. 我寧殺彼隋那落迦, 終不令其受無間苦. 如是於彼, 或以善心或無記心, 知 此事已, 為当来故樑生慚愧, 以憐㟲心而断彼命. 由此因縁, 於菩薩戒無所違犯, 生多功 德. 此關煩惱故無違犯. 意楽善故生多功徳. 今解不然. 不成業道, 亦成犯故. 如諸有命皆 犯重処，雖想顛倒而犯重故．（T40.703c04）

この文は『法蔵疏』にも引用されているが, 法蔵・勝莊・義寂はこれを根拠と して菩薩行の殺生を許している. しかし, 太賢は従来の無違犯を理解しつつも, 「今解不然. 不成業道, 亦成犯故」と言ってそれを否定し, 善心のみならず無記 心や顛倒などの全ての殺生を禁じている。この殺生に対する罪の判断は義寂と類 似しているが, 義寂は殺した「非人」を後に人と思えば, 根本は犯さないが罪は あると説く ${ }^{11)}$. しかし, これは特殊な例であって, 彼も菩薩は利益があれば犯し ても許されると説く．太賢が全ての殺生を禁ずるのは「第一快意殺生戒」の制定 理由とも関連があり, 太賢は他人の命を奪うのは最も酷い行動であると説く ${ }^{12)}$. したがって, 菩薩はたとえ方便であっても他人の命を絶ってはならないのであ る.

太賢と義寂の影響関係は四十八軽戒の科文にもあらわれている。太賢は四十八 軽戒を五項（十戒・十戒・十戒・九戒・九戒）に分けているが, 中の「第十一通国使 命戒～第二十不救存亡戒」「第二一不忍違犯戒～第三十詐親害生戒」「第四十摂化 漏失戒〜第四八自破内法戒」の説明が『義寂疏』とほぼ同様である ${ }^{13)}$.また，太 賢は衆生の仏性について『涅槃経』を引用して仏性の有無を疑うのは三宝を謗る ことであると説くが, 同じ引用文が『義寂疏』にも引用されている ${ }^{14)}$.これは 「一切衆生悉有仏性」に基づいたもので, 勝莊の「五性各別説」とは反対の見解 である ${ }^{15)}$.

他にも，太賢は「第十畜殺生具戒」で『涅槃経』を引用し，在家の正法守護の ための武器所持を許しているが, 義寂も同じ引用文を用いて許している ${ }^{16)}$. 但 し義寂はそれが殺生に至ってはならないという限定を加えている。「第十一通国 
使命戒」では，菩薩が善心で争いなどを止めるために政治介入するのを許してい るが，これは法蔵とかなり類似した註釈である ${ }^{17)}$ 。さらに，二人は同じく仏弟子 を内護, 国王を外護として設定し, 僧伽と国家を調和させて仏法守護と護国仏教 を宣揚する註釈をした ${ }^{18)}$ 。また「金山寺慧徳王師真応塔碑」(高麗, 1111 年) では， 新羅の『瑜伽論』教学は元暁が前で導いて太賢がその後を継ぐと記され ${ }^{19)}$, 高麗 時代から元暁と太賢の関係性が認められていたことを明らかにしている.

しかし, 崔源植の主張とは違って, 『古迹記』における勝莊の影響はほとんど なかったであろうと考えられる。まず，勝莊は「五性各別説」の仏性論を用いた ので，太賢とは根本的に異なる，また，勝莊は『瑜伽論』を優位に置いてその中 に『梵網経』を含ませるための註釈であったので，太賢の『梵網経』中心の註釈 とは性格が異なる。これらについては崔源植も認めているが, それにもかかわら ず同じ新羅出身なので勝莊の間接的な影響があったであろうと主張している ${ }^{20)}$. ところが, 崔 $(1999,124)$ は仏性論について, 新羅の唯識学派は一切衆生に仏性が あると認めるので，勝莊は彼らとは見解を異にしていたと説く．また，『古迹記』

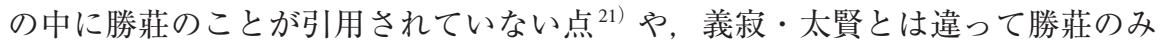
が在家の奴婢所有を認める点なども，太賢との関係性を浅くする。したがって， 同じ『瑜伽論』を引用したことや同じ新羅出身であったことで, 勝莊と太賢の影 響関係を主張するのは多少無理があると考えられる.

以上のように，太賢は『古迹記』で従来の註釈より一層積極的に三聚浄戒を用 い，『梵網経』の諸戒に七衆戒を含ませたり，「一分受」や「自誓受戒」などを許 したりした。 また, 戒の根本を仏性と見, それは「性相不二」の空性であると説 く、しかし，『瑜伽論』を引用して空性も実は方便であって，空もまた空である ことを理解したとき，究竟の菩薩行を修すると述べる。

太賢は『梵網経』の「十重四十八軽戒」の13箇所で『瑜伽論』を引用して註釈 した．特に無違犯の根拠として『瑜伽論』を用いている．新羅瑜伽宗の祖師とも 称される太賢が『瑜伽論』を用いるのは当然であるが，従来のように『瑜伽論』 を通して無違犯をすべて認めたのではなく，菩薩の根本に反する場合はそれを否 定した。これは太賢が『梵網経』の「古迹」をそのまま踏襲したのではなく，そ れを土台に独自の註釈をしたことを示す。

『古迹記』の影響関係については, 従来の元暁・法蔵の他に義寂との関係性が あることも確認した。しかし，勝莊との関係に関しては，仏性論や註釈の性格な どに大きな違いがあるので, 従来の勝莊の影響説は多少無理がある主張であると 
考えられる，つまり，太賢は『梵網経』中心の註釈とも言われる元暁・法蔵・義 寂から影響を受けて『古迹記』を著したであろうと考えられる.

1) 蔡 (1977, 391-436), 崔 (1999, 185-216) を参照.

2）必由律儀得後不共二菩薩戒. 故作是説. 未必菩薩先発小心.（T40.703a）

3）発此心已有二種受. 一者一分受，随其受者意楽所堪. 或受一戒，或多皆得成戒名為菩 薩．不同声聞必総受持，若其一分不名比丘.（T40.700b）

4）受律儀戒方軌有二. 一与餘二總受. 二与餘二別受. 總受方軌七衆無別...若別受者七衆 法異. (T40.658a)

5）但解師語発心皆得. 雖但解語, 唯受一戒, 猶勝二乗一切功徳. 羅漢功徳但為自身, 於 有情界無有恩分. 菩薩一戒爲度一切. 無一衆生不荷恩故.（T40.700b）

6）智顗は「六種受戒」の「瓄珞本」の説明で,「自誓受戒」を下品の受戒であると説く. 若真仏菩薩前受者, 名上品戒. 若仏滅後, 千里内無仏菩薩, 從前受者為師, 名中品戒. 若千里内無法師，從仏菩薩像前自誓受者，名下品戒也．（T40.569a04）

7）自受羯磨如菩薩地四十一説, 若千里内等者, 若爾自受功徳劣耶. 不爾. 雖無現縁, 心 猛利故. 如五十三云, 自受從他若等心受亦如是持. 福徳無別. (T40.712c01）

8）因果万徳以戒為初。名曰本源。如下広釈. 仏性種子者戒実性也.（T40. 700a06）

9）如瑜伽云, 於空性相有失壊者, 便為失壊一切大乗。是以菩薩行六度時, 皆無所得以為 方便. 無所得者即不住道. 若唯空有便可得無. 而復空空故無所得. 無所得故三輪清淨. 是名究竟修菩薩行.（T40.690a22）

10) 崔 (1999, 187-200).

ところが崔源植は論文の末尾で，太賢と義寂は「瑜伽戒」を中心に「梵網戒」を包摂し ようとした意図が見えないので, 勝莊とは引用の立場が異なっていると述べる. 崔 $(1999,194)$

11）義寂：後非人人想雖不犯本一向有罪．犯方便故.（T40.664a23）

法蔵は, 犯は無いが業の有無は場合によって異なると説く. 勝莊は, 殺生は有るが殺生 罪は無いと説く.

12）初制意者，世間所畏死苦為窮，損他之中無過奪命。（T40.703b22）

13）太賢：自下十戒分為二門．初四護自善門，後六護攝他門．（T40.710c19）

自下十戒成六和敬. 謂十如次三一四二摂彼業見利戒同故. 初三各摂三業同故成六和敬. (T40.712a27)

自下九戒初五以戒摂受. 後四以悲教化.（T40.716a16）

義寂：第二十戒中，初四戒摂自行善，後六摂化他善.（T40.674a08）

自下第三十戒明摂和敬之善. 和敬有六, 謂三業同, 及戒見利同. 於十戒中, 初三戒明三 業同，次一明見同，次四明利同，後二明戒同.（T40.677a29）

第二九戒中, 初五戒并以戒法摂受, 後四戒并以悲心教化.（T40.684c01）

14）太賢：如涅槃經．若説衆生定有佛性定無佛性．皆爲謗佛法僧寶也．（T40.711c02）

義寂：如涅槃説也．若説衆生定有佛性定無佛性．皆謗佛法僧也（T40.676a02）

15) 崔 $(1999,205-206)$.

16）太賢：言犯軽垢罪者，若護正法即無違犯。涅槃経中在家護法聴持択杖故.（T40. 710c17)

義寂：又雖非貴人, 若欲護法備器杖, 防無害心者, 亦応開之. 涅槃経中在家人為欲護 法, 故聴持器杖. 但不得至殺. (T40.674a03)

17）太賢：菩薩理応和諸違猙. 而通国使命相殺害違菩薩道, 故今制也. 若為調伏止長相殺 
入国. 理応無犯. (T40.710c24)

法蔵：若以善心為調伏彼令其和穆，入軍入国一切無犯.（T40.639c23）

18）太賢：仏法付属両人. 一仏弟子以為内護, 二諸国王以為外護.（T40.717a29）

法蔵：仏法付属二人。一仏弟子為内護, 二国王為外護.（T40.653b14）

19）唐文皇以新羅王表請宣送瑜伽論一百卷，於是無応理圓実之学漸盛于茲土．暨乎暁法師 導之于前, 賢大統踵之於後, 燈燈伝世世嗣興. (李（1996）を参照).

20) 崔 $(1999,194)$.

21）蔡（1977, 403-408）によれば, 『古迹記』の中に「如戒本記」という異称で勝莊の『述 記』が言及されたというが，それは引用ではなく引証であると主張する.

〈参考文献〉

蔡印幻 1977 『新羅仏教戒律思想研究』国書刊行会.

石井公成 1983 『華厳思想の研究』春秋社.

吉津宜英 1991 『華厳一乗思想の研究』大東出版社.

崔源植 1999 『新羅菩薩戒思想史研究』ソウル：民族社.

李智冠 1996 『校勘訳註歴代高僧碑文：高麗篇3』ソウル：伽山文庫.

〈キーワード〉『梵網経』, 『古迹記』, 太賢, 義寂, 勝莊

(花園大学国際禅学研究所客員研究員)

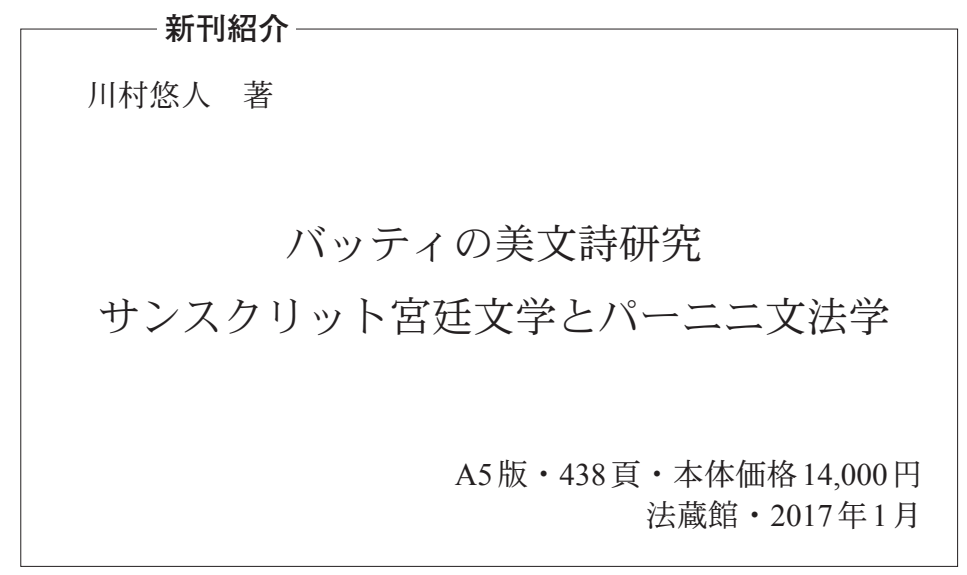

